\title{
PALYNOLOGICAL RESEARCHES CONCERNING THE PONTIAN ON THE VIŞENILOR VALLEY AND BOEREASCA VALLEY - NE OF DROBETA TURNU SEVERIN (SW ${ }^{\mathrm{RN}}$ ROMANIA)
}

\author{
IUSTINIAN PETRESCU ${ }^{1}$, NICOLETA BICAN-BRIŞAN ${ }^{1}$, \\ CORNEL MEILESCU ${ }^{2}$, ION PĂTRUȚOIU ${ }^{3}$
}

\begin{abstract}
Palynological analyses in the sections of Vişenilor Valley and Boereasca Valley (Upper Pontian (Bosphorian)) are presented in table 1. In the second part of paper, the authors made a comparison between microflora from Mehedinți and other Pontian microfloras in Romania and from abroad (former Yugoslavia, Hungary, and Slovakia).
\end{abstract}

KEYWORDS: microflora, Late Miocene (Pontian), Vişenilor Valley, Boereasca Valley, SW ${ }^{\text {rn }}$ Romania.

\section{Introduction}

The studied area is located in the south-western part of Romania (Mehedinți County). The Vişenilor and Boereasca Valleys are the left side tributaries of the Pleşuva Valley, which (in it turn) flow into the Topolnița Valley (Fig.1).

There is a deep digging section on the Vişenilor Valley (Fig.2). Its the basal part preserved Middle Pontian (Portaferian) deposits (Marinescu, 1978).

The lower part of the section, considerated as the base of Upper Pontian (Bosphorian) consists of silty marly clays with rare remains of Paradacna abichi.

The fossiliferous sandy clays from above contain remains of Paradacna abichi, Valenciennius, Phyllocardium planum planum, Limnocardium div.sp., Didacna otiophora, Congeria digitifera, etc. (Marinescu, 1978).

The yellowish sand level with cross lamination, without fossil remains, from above is considerated as the last Pontian deposits.

In this area, the thickness of Upper Pontian exceeds $25 \mathrm{~m}$.

The Pliocene deposits occur in unconformity above the Pontian deposits. The Dacian consists of nonfossiliferous sands and alternation of gray clays and sands with coals. The sequence from the upper part consists of clays and sands considerated as Romanian. Valley.

A similar profile (Fig.2) occurs south of Vişenilor Valley, on the Boereasca

Lithologicaly, Upper Pontian deposits from this section are represented by less fossiliferous marly clays that include intercalations of fossiliferous gray clay levels. The fossil remains are identically with those ones from the Vişenilor Valley.

Sandy clays and, in the upper part, a yellowish sands level occur above these deposits.

On the Boereasca Valley, the Upper Pontian is about $35 \mathrm{~m}$ thick.

\footnotetext{
${ }^{1}$ Babeş-Bolyai University, 1 Kogălniceanu str., 3400 Cluj-Napoca, Romania

264 / 9 Alion str., 1500 Drobeta Turnu Severin, Romania

${ }^{3}$ S.C. ICSITPML S.A. Craiova, Romania
} 
Fig. 1. Location of the studied area (1 - Cuaternar, 2 - Romanian, 3 - Dacian, 4 - Pontian, 5 - geological boundary) (after geological map of Romania,

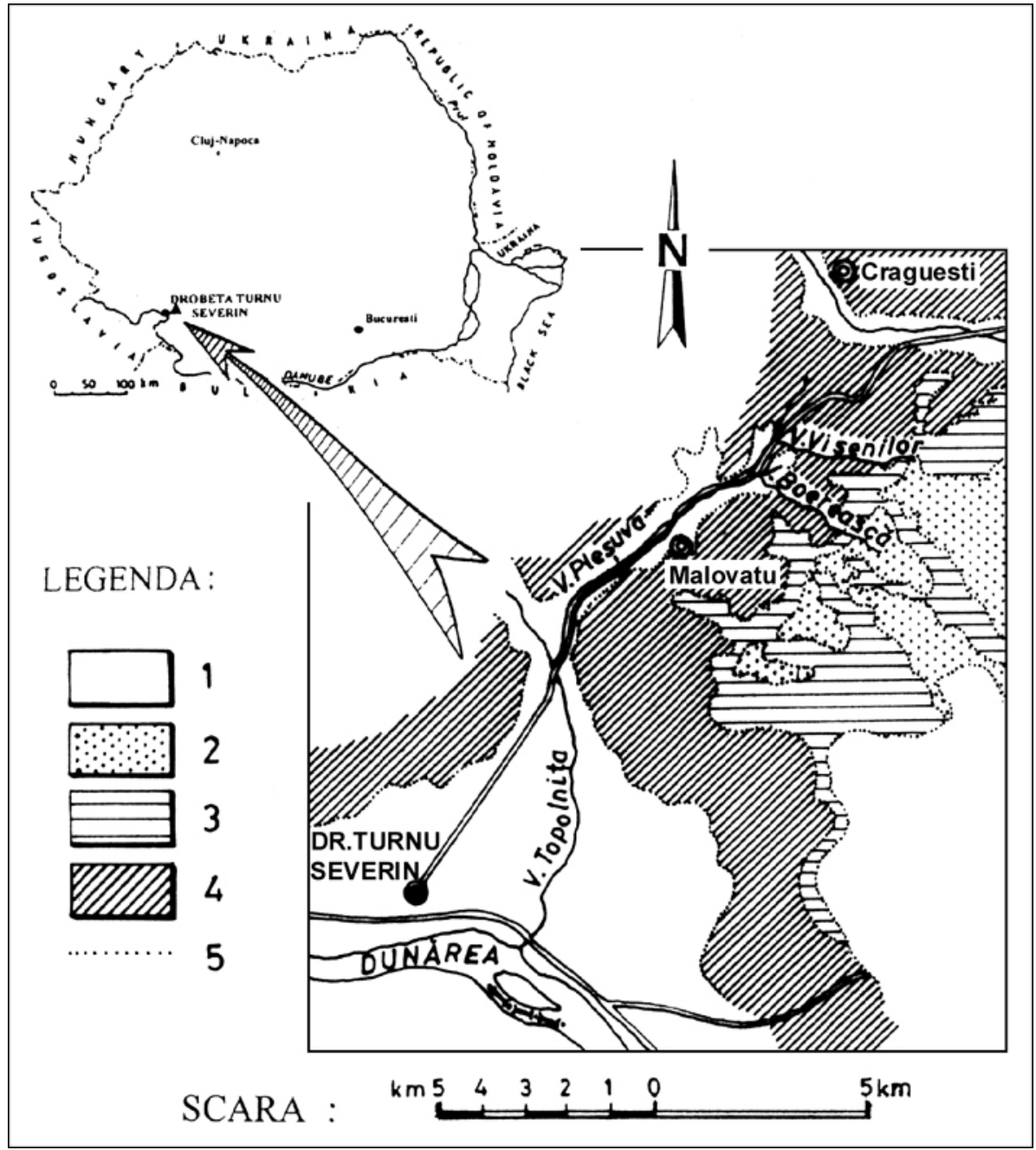

scale 1:200.000, with modifications).

On the Urdă brook, a sandy dominant sequence (about $7 \mathrm{~m}$ ) occurs which has an intercalation of coal clay that belongs to "level A" of Lower Dacian.

On other brook (Hudoame), the Lower Dacian, predominant sandy (about $10 \mathrm{~m}$ ) contains I and IV coal levels.

The Pontian on the Vişenilor Valley, Boereasca Valley and the adjacent area, was monographically studied from the faunistic and biostratigraphic point of views a by Marinescu (1978). 
Recently, Pătruțoiu (2000) presented a well-informed $\mathrm{PhD}$ thesis concerning the Pliocen with lignites between Danube and Motru, but also containing pertinent information about the Pontian from Mehedinți (I.c. p. 21-22).

We mention that, from the Upper Pontian on the Vişenilor Valley, Givulescu (1976) described a nut of Juglans bergonensis and a cone of Pinus sp.

\section{Palynological analyse}

8 samples were collected from the clayey levels of the Vişenilor Valley. The samples labeled 3,4 and 7 are very representatively, and for these samples we presented the pollinic diagrams (Fig.3). The upper part of the section considered as Dacian, preserves a rich palynological content which is not the subject of this paper.

7 samples were collected from the Upper Pontian (Bosphorian sequence of the Boereasca Valley, more conclusive being those ones labeled 1 and 4 . The upper part of the profile (samples $8-14$ ) belongs to the Dacian and preserves a rich microflora.

From palynological point of view, the Upper Pontian from the Boereasca Valley had the same specific features as the Pontian from Vişenilor Valley and we shall refer at the last of them in the following paragraphs. Also, we mention that, sample 4 (Boereasca Valley) resembles the Upper Pontian sample from Dedovița Valley (Petrescu, Mălan, 1991). The pollen of Cedrus is also frequent in this sample.

As we can see in the palynological diagrams (Fig. 3) the FERNS show low frequencies $(2-4 \%)$ in the Upper Pontian on the Vişenilor Valley. Most of them belong to Polypodiaceae family (more frequent is Laevigatisporites haardti, followed by Leiotriletes wolffi). Rarely, appear in the spectrum Leiotriletes asp. microsinuosoides W. Kr. 1967 and Polypodiaceoisporites cyclocingulatus W. Kr. 1967.

The spores of Osmundaceae: Baculatisporites quintus (Th.-Pf.1953) W. Kr. 1967 and Baculatisporites primarius (Wolff 1934) Th.-Pf. 1953 are also rare.

The spores of Stereisporites (MUSCI) are qualitatively well diversified but quantitatively, they not exceed $1 \%$.

In the profile from Vişenilor Valley, the CONIFERS have a variable frequence between 34 and $47 \%$; always, it can be remarked the predominance of Pinaceae forms.

The pollen of Cupressaceae - Taxodiaceae is quantitatively subordinate $(1-$ 2 \%). Rarely appear grains of Cupressacites bockwitzensis W. Kr.1971, Inaperturopollenites concedipites (Wodeh. 1933) W. Kr. 1971, Inaperturopollenites hiatus (Pot. 1931) Th.-Pf. 1953, Sequoiapollenites polyformosus Thiergart 1937, Sciadopityspollenites serratus (Pot.-Ven. 1934) Thiergart 1937, Sciadopityspollenites verticillatiformis (Zauer 1960) W.Kr. 1971.

The pollen of Pinaceae (33-45\%) belongs to the Pinus genus (sg. haploxylon and sg. diploxylon), which is frequent to very frequent, Tsuga - frequent, Abies rare, Cedrus - rare to frequent, Picea - rare. 
IUSTINIAN PETRESCU, NICOLETA BICAN-BRIŞAN, CORNEL MEILESCU, ION PĂTRUṬOIU

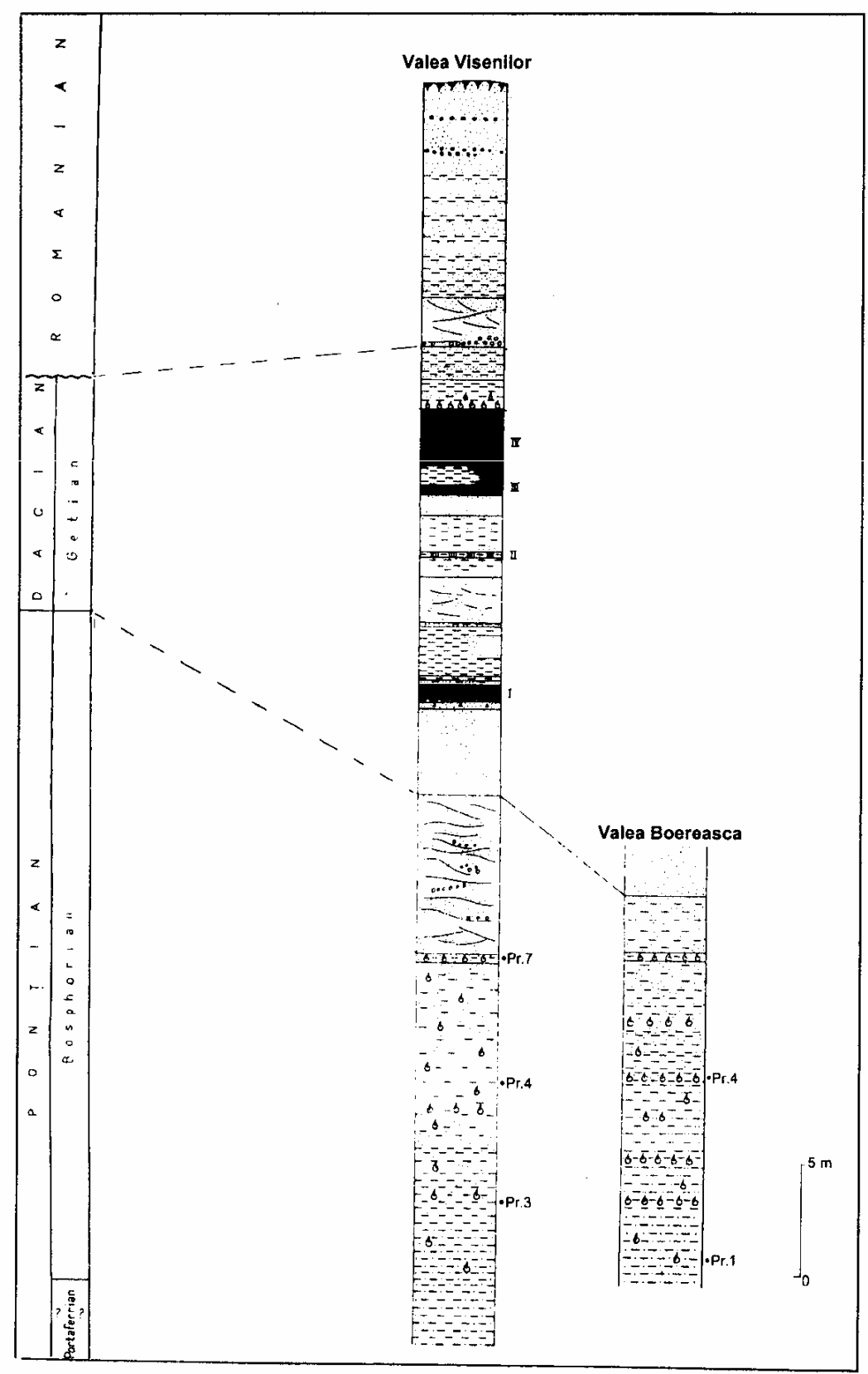

Fig.2. Synthetic lithologic columns on the Vişenilor Valley and Boereasca Valley (after Marinescu, 1978 with modifications) 


\section{Diagram V3}

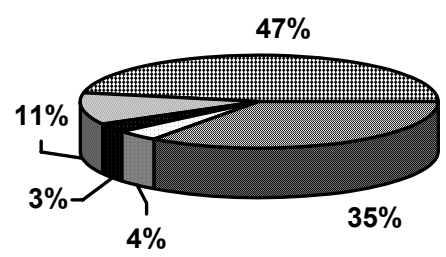

口Ferns (4\%)

Dinoflagellates (3\%)

$\square$ Reworked forms (11\%)

Donifers (47\%)

$\square$ Angiosperms (35\%)

\section{Diagram V4}

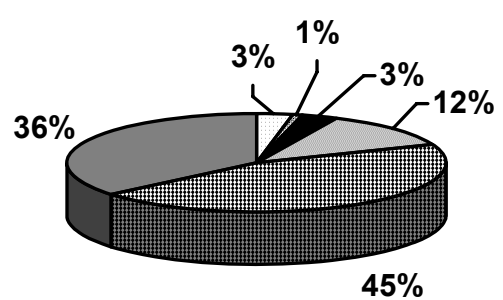

$$
\begin{aligned}
& \text { 口Ferns (3\%) } \\
& \square \text { Ephedra (1\%) } \\
& \text { —Botryococcus (3\%) } \\
& \square \text { Reworked forms (12 } \\
& \text { ⿴囗十) Conifers (45\%) } \\
& \square \text { Angiosperms (36\%) }
\end{aligned}
$$

\section{Diagram V7}

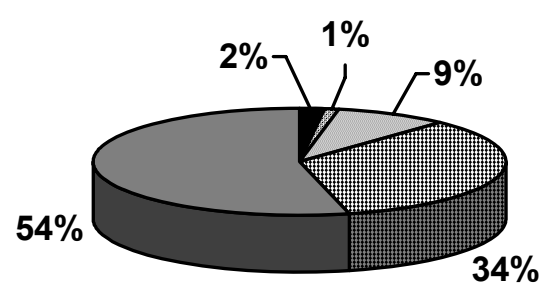

\section{- Ferns (2\%) \\ 口Ephedra (1\%)}

$\square$ Reworked forms $(9 \%)$

⿴囗十) Conifers (34\%

$\square$ Angiosperms (54\%)

Fig.3 Pollinic diagrams for the Pontian from Vişenilor Valley (samples 3, 4 and 7)

Other details may be seen in table 1 .

The CLAMIDOSPERMATOPSIDS are represented by pollen of Ephaedraceae that is present in all the analyzed samples. Because of its paleoecological significance, the presence of this pollen must be noticed. 
MONOCOTYLEDONOUS ANGIOSPERMS are always quantitatively subordinate (1-2\%). Monoporate grains represent them: Graminiidites, Sparganiaceaepollenites. The monocolpate grains of palms (Monocolpopollenites, Arecipites) are scarce.

Table 1

List of pollen-spores taxa identified in the Pontian deposits (sample $3,4,7$ ) from studied area and their frequency.

\begin{tabular}{|c|c|c|c|}
\hline \multirow[t]{2}{*}{ TAXA } & \multicolumn{3}{|c|}{ FREQUENCY } \\
\hline & V3 & V4 & V7 \\
\hline CHLOROPHYTA. & & & \\
\hline $\begin{array}{l}\text { Botryococcus braunii Kutz. } 1949 \\
\text { PTERIDOPHYTA. FILICOPSIDA }\end{array}$ & + & + & + \\
\hline Laevigatisporites haardti (Pot. et Ven. 1934) Th. et Pf. 1953 & ++ & ++ & ++ \\
\hline Leiotriletes wolffi W. Kr. 1962 & ++ & ++ & ++ \\
\hline Leiotriletes asp. microsinuosoides W. Kr. 1967 & + & + & + \\
\hline Polypodiaceoisporites cyclocingulatus W. Kr. 1967 & + & + & + \\
\hline Baculatisporites quintus (Th.-Pf. 1953) W. Kr. 1967 & + & + & + \\
\hline $\begin{array}{l}\text { Baculatisporites primarius (Wolff 1934) Th.-Pf. } 1953 \\
\text { BRYOPHYTA. MUSCI }\end{array}$ & + & + & + \\
\hline Stereisporites (St.) involutus nochtenensis W. Kr. - Sontag 1963 & $x$ & $x$ & $x$ \\
\hline Stereisporites (St.) stereoides stereis (W. Kr. 1959) W. Kr. 1963 & $\mathrm{x}$ & $\mathrm{x}$ & $\mathrm{x}$ \\
\hline $\begin{array}{l}\text { Stereisporites (St.) strictus woelfersheimensis (W. Kr. 1959) - } \\
\text { W.Kr.1963 }\end{array}$ & $x$ & $\mathrm{x}$ & $x$ \\
\hline Stereisporites (St.) megastereis W. Kr. 1963 & $x$ & $x$ & $\mathrm{x}$ \\
\hline $\begin{array}{l}\text { Stereisporites (St.) tristereoides W. Kr. } 1963 \\
\text { GYMNOSPERMATOPHYTA. } \\
\text { CONIFEROPSIDA }\end{array}$ & $\mathrm{x}$ & $x$ & \\
\hline Abiespollenites absolutus Thg. 1937 & $x$ & $\mathrm{x}$ & $x$ \\
\hline Abiespollenites cedroides (Thomson 1953) W. Kr. 1971 & $x$ & $x$ & $x$ \\
\hline Abiespollenites crassus Nagy 1969 & $\mathrm{x}$ & $x$ & $x$ \\
\hline Abiespollenites dubius (Chlonova 1960) W. Kr. 1971 & $\mathrm{x}$ & $x$ & $\mathrm{x}$ \\
\hline Abiespollenites latisaccatus (Trevisan 1967) W. Kr. 1971 & + & + & $\mathrm{x}$ \\
\hline Abiespollenites maximus W. Kr. 1971 & + & + & $x$ \\
\hline Pinus sg. haploxylon & ++ & ++ & + \\
\hline Pinus sg. diploxylon & ++ & +++ & ++ \\
\hline Piceapollis planoides W. Kr. 1971 & $\mathrm{x}$ & $\mathrm{x}$ & $\mathrm{x}$ \\
\hline Piceapollis praemarianus W. Kr. 1971 & $x$ & $\mathrm{x}$ & $\mathrm{x}$ \\
\hline Piceapollis tobolicus (Panova 1966) W. Kr. 1971 & $\mathrm{x}$ & $x$ & $\mathrm{x}$ \\
\hline Cedripites crassiundulicristatus (Stelmak 1960) W. Kr. 1971 & $\mathrm{x}$ & & \\
\hline Cedripites deodaraesimilis (Nagy 1969) Nagy 1985 & ++ & ++ & ++ \\
\hline Cedripites sp. & $\mathrm{x}$ & $\mathrm{x}$ & $\mathrm{x}$ \\
\hline Zonalapollenites gracilis W. Kr. 1971 & $\mathrm{x}$ & ++ & $\mathrm{x}$ \\
\hline Zonalapollenites igniculus (Pot. 1931) Th. et Pf. 1953 & $\mathrm{x}$ & + & $\mathrm{x}$ \\
\hline Zonalapollenites maximus (Raatz 1937) W. Kr. 1971 & ++ & +++ & ++ \\
\hline Zonalapollenites spinulosus W. Kr. 1971 & $\mathrm{x}$ & $\mathrm{x}$ & + \\
\hline Sciadopityspollenites serratus (Pot. et Ven. 1934) Thg. 1937 & $x$ & $x$ & $x$ \\
\hline Sciadopityspollenites verticillatiformis (Zauer 1960) W. Kr. 1971 & $\mathrm{x}$ & $\mathrm{x}$ & $\mathrm{x}$ \\
\hline Sequoiapollenites polyformosus Thg. 1937 & $\mathrm{x}$ & $\mathrm{x}$ & $x$ \\
\hline
\end{tabular}


PALYNOLOGICAL RESEARCHES CONCERNING THE PONTIAN ON THE VIŞENILOR VALLEY ...

\begin{tabular}{|c|c|c|c|}
\hline \multirow[t]{2}{*}{ TAXA } & \multicolumn{3}{|c|}{ FREQUENCY } \\
\hline & V3 & V4 & V7 \\
\hline $\begin{array}{l}\text { Inaperturopollenites concedipites (Wodeh. 1933) W. Kr. } 1971 \\
\text { Cupressacites bockwitzensis W. Kr. } 1971 \\
\text { CHLAMIDOSPERMOPSIDA }\end{array}$ & $\mathrm{x}$ & $\mathrm{x}$ & $\mathrm{x}$ \\
\hline Ephedripites (D.) fusiformis (Shakmundes 1965) W. Kr. 1970 & $x$ & $\mathrm{x}$ & $\mathrm{x}$ \\
\hline $\begin{array}{l}\text { Ephedripites (D.) tertiarius W. Kr. } 1970 \\
\text { ANGIOSPERMATOPHYTA. } \\
\text { MONOCOTYLEDONATAE }\end{array}$ & $\mathrm{x}$ & & \\
\hline Graminidites subfiliglobosus (Trevisan 1967) W.Kr. 1970 & $\mathrm{x}$ & $\mathrm{x}$ & $\mathrm{x}$ \\
\hline Sparganiaceaepollenites polygonalis Thiergart 1937 & $x$ & $\mathrm{x}$ & $\mathrm{x}$ \\
\hline Monocolpopollenites sp. & & $\mathrm{x}$ & \\
\hline $\begin{array}{l}\text { Arecipites sp. } \\
\text { DICOTYLEDONATAE }\end{array}$ & $\mathrm{x}$ & & \\
\hline Slowakipollis cechovici (Pacltova 1958) W. Kr. 1962 & & & $\mathrm{x}$ \\
\hline Triatriopollenites myricoides (Kremp 1950) Th. et Pf. 1953 & $\mathrm{x}$ & $\mathrm{x}$ & $\mathrm{x}$ \\
\hline $\begin{array}{l}\text { Engelhardtioidites microcoryphaeus (Pot. 1931) Thomson et } \\
\text { Thg. ex Pot. } 1960\end{array}$ & $x$ & $x$ & $x$ \\
\hline Momipites punctatus (Pot. 1931) Nagy 1969 & $\mathrm{x}$ & $\mathrm{x}$ & \\
\hline Caryapollenites simplex (Pot. 1931) W. Kr. 1960 & + & + & + \\
\hline Pterocaryapollnites stellatus (Pot. 1931) Thg. 1937 & $\mathrm{x}$ & + & + \\
\hline Ulmipollenites undulosus Wolff 1934 & $\mathrm{x}$ & $x$ & $x$ \\
\hline Zelkovaepollenites potoniei Nagy 1969 & $x$ & $x$ & $x$ \\
\hline Trivestibulopollenites betuloides Pflug 1953 & + & + & ++ \\
\hline Alnipollenites verus (Pot. 1931) Pot. 1934 & + & + & + \\
\hline Carpinipites carpinoides (Pf. 1953) Nagy 1985 & $\mathrm{x}$ & $x$ & $\mathrm{x}$ \\
\hline Triporopollenites coryloides Pf. 1953 & $x$ & $x$ & $x$ \\
\hline Salixipollenites cineraeformis Planderova 1990 & $x$ & $x$ & + \\
\hline Salixipollenites verus Planderova 1972 & $x$ & $x$ & + \\
\hline Malvacearumpollenites bakonyensis Nagy 1962 & $\mathrm{x}$ & $x$ & \\
\hline Intratriporopollenites cordataeformis (Wolff 1934) Mai 1961 & $x$ & $x$ & $\mathrm{x}$ \\
\hline Intratriporopollenites insculptus Mai 1961 & $\mathrm{x}$ & $x$ & $\mathrm{x}$ \\
\hline Intratriporopollenites instructus (Pot. 1931) Th. et Pf. 1953 & $\mathrm{x}$ & $x$ & $\mathrm{x}$ \\
\hline Corsinipollenites oculusnoctis (Thg. 1940) Nakoman 1960 & $\mathrm{x}$ & & \\
\hline Lonicerapollis gallwitzi W. Kr. 1962 & & $\mathrm{x}$ & \\
\hline Scabiosaepollenites minimospinuosus Nagy 1969 & $\mathrm{x}$ & $\mathrm{x}$ & $\mathrm{x}$ \\
\hline Valerianaceoipollenites neszmelyensis Nagy 1992 & $\mathrm{x}$ & $\mathrm{x}$ & \\
\hline Aceripollenites rotundus Nagy 1969 & & $\mathrm{x}$ & \\
\hline Umbeliferuspollenites tenuis Nagy 1985 & $\mathrm{x}$ & $\mathrm{x}$ & \\
\hline Periporopollenites stigmosus (Pot. 1931) Th. et Pf. 1953 & & $\mathrm{x}$ & \\
\hline Persicarioipollis franconicus W. Kr. 1962 & $\mathrm{x}$ & $\mathrm{x}$ & $\mathrm{x}$ \\
\hline Tubulifloriidites ambrosinae Nagy 1969 & $\mathrm{x}$ & & \\
\hline Tubulifloriidites granulosus Nagy 1969 & $x$ & & \\
\hline Tubulifloriidites macroechinatus (Trevisan 1967) Nagy 1969 & $x$ & $\mathrm{x}$ & \\
\hline Tubulifloriidites grandis Nagy 1969 & $\mathrm{x}$ & $\mathrm{x}$ & \\
\hline Chenopodipollis multiplex (Weyl. et Pf. 1957) W. Kr. 1966 & + & ++ & ++ \\
\hline Chenopodipollis maximus Nagy 1969 & & $\mathrm{x}$ & \\
\hline Caryophyllidites microreticulatus Nagy 1969 & $\mathrm{x}$ & & \\
\hline
\end{tabular}


IUSTINIAN PETRESCU, NICOLETA BICAN-BRIŞAN, CORNEL MEILESCU, ION PĂTRUṬOIU

\begin{tabular}{|l|c|c|c|}
\hline \multicolumn{1}{|c|}{ TAXA } & \multicolumn{3}{c|}{ FREQUENCY } \\
\cline { 2 - 4 } & $\mathrm{V3}$ & $\mathrm{V} 4$ & $\mathrm{~V} 7$ \\
\hline Eucommiapollis eucommi (Planderova) 1990 Petrescu-Bican Brisan- & $\mathrm{x}$ & $\mathrm{x}$ & $\mathrm{x}$ \\
Mera 1999 & & & \\
Quercopollenites petraea Nagy 1969 & $\mathrm{x}$ & $\mathrm{x}$ & $\mathrm{x}$ \\
Quercopollenites robur Nagy 1969 & $\mathrm{x}$ & $\mathrm{x}$ & $\mathrm{x}$ \\
Faguspollenites verus Raatz 1937 & $\mathrm{x}$ & $\mathrm{x}$ & $\mathrm{x}$ \\
Nyssapollenites kruschi (Pot. 1931) Nagy 1969 & & $\mathrm{x}$ & \\
llexpollenites iliacus (Pot. 1935) Thg. 1937 & $\mathrm{x}$ & & \\
Artemisiaepollenites sellularis Nagy 1969 & $\mathrm{x}$ & $\mathrm{x}$ & $\mathrm{x}$ \\
Ericipites callidus (Pot. 1931) W. Kr. 1970 & $\mathrm{x}$ & $\mathrm{x}$ & \\
\hline
\end{tabular}

Frequecy::

$$
\begin{aligned}
& \text { +++ - very frequent }(21-30 \text { grains }) \\
& ++ \text { - frequent }(10-20 \text { grains }) \\
& \text { + - rare }(3-9 \text { grains }) \\
& \text { x - very rare }(1-2 \text { grains })
\end{aligned}
$$

The DICOTYLEDONS are numerous and of a large diversity (Tab.1). In samples labeled 3 and 4 dicotyledonous angiosperms are subordinate to conifers (34-35\%), but in sample 7 these ones dominate clearly (52\%).

The thermophile Miocene elements continue to be present but always they are rare or very rare (Triatriopollenites myricoides, Engelhardtioidites microcoryphaeus, Momipites punctatus, s.a. On the other hand, the mesotherme elements continue to be relative well represented: Caryapollenites, Pterocaryapollenites, Zelkovaepollenites, Intratriporopollenites, a.o.

The arctotertiary elements are the most numerous as part of dicotyledons, too: Carpinipites, Salixipollenites, Quercopollenites, Faguspollenites, a.o. Obviously, the temperate pinaceae (Picea, Tsuga, a.o.) represented an mountain forestry belt very well praised. There is no doubt that the distribution of the microtherme deciduous trees (Quercus type petraea, type robur, Fagus, a.o.) and of temperate pinaceeans (Pinus pr.p., Abies, Tsuga, Picea) according to altitude is related to the raising of Carpathians in close proximity with the sedimentary basin. The orogenetic movements belong to the Attican orogenetic event are indirectly proved by this distribution of forests according to altitude and also by the reworked forms of the prepontian palynomorphs which reach to $9 \%$ in sample 7 with superior stratigraphic position (at the end of the Pontian).

It is to remark the pollen of herbaceous plants (Chenopodipollis, Caryophyllidites, Tubulifloridites, Artemisiaepollenites, a.o.) which is related to continentalization of the climate, easy to be proved from palynological point of view at the end of the Miocene and in Pliocene.

From biostratigraphical point of view, among the forms which must be remarked, are: Stereisporites (Tab.1), also some dicotyledonous angiosperms such as: Intratriporopollenites cordataeformis, Scabiosaepollenites minimospinuosus, Valerianaceoipollenites neszmelyensis, Persicariopollis franconicus, etc. (c.f. Nagy, 1992, pag. 366). 
The relation between studied microflora and other Pontian microflora from Romania and abroad.

Several sections of Pontian age, in western part of Romania, was studied. Thus, the Pontian with lignite from Sărmăşag, Şimleu Basin, has been studied from palynological point of view (Petrescu et al., 1982). The ferns, quantitatively have a participation of $15 \%$ and are dominate by Polypodiaceae (more frequent are the spores of Laevigatisporites haardti). The conifers represent $31 \%$ and are dominated by the representatives of Pinaceae family. The pollen of Taxodiaceae + Cupessaceae totalizes $2,5 \%$. The dicotyledonous angiosperms dominate the pollinic spectrum $(36 \%)$ and the monocotyledons are subordinate (less than 1\%).

The peat bog from Sarmasag is proved by the presence of foliar imprints in Pontian from Bihor: Derna - Voievozi, too (Maxim, Petrescu, 1968). The Pontian was studied from palynological point of view, from many boreholes from Roşiori area (Oradea-north) and Voievozi (Petrescu, Nicorici, 1979), respectively Oradea-east (Petrescu et al., 1979). The most representative was the borehole 3335 - Voievozi in which was remarked a vertical succession of some characteristics pollen-spores depending on the evolution of peat bog (generating by coals) and of adjacent areas.

Petrescu et al. (1982) studied from palynological point of view the Pontian from some boreholes placed in Vişag and Sinersig sectors from Lugoj Basin. The peat bog pollen-spores assemblages that lie at the base are well represented. The microflora from Darova sector (Petrescu, Kolovas, 1982) is similar to above-mentioned microflora.

In the southern part of Carpathians, there is palynological data concerning the Pontian that accur between Cricovul Sărat Valley (west) and Tohăneasca Valley (east) from Muntenia (Roman, Papaianopol, 1982). Being the only palynological paper concerning the Pontian deposits from southern part of Romania, further we make some references about this. The Lower Pontian (Odessian) is dominated by pollen belonging to: Quercus, Carya, Pterocarya, Ulmus, Zelkova. Mainly Pinus and Picea represent the conifers. The pollen of herbaceous plants belong to Chenopodiaceae and Atemisia. The presence of dinoflagellates (Gonyaulacaceae) proves a brackish-eurihaline environment. In the Middle Pontian (Portaferrian) increase the percentage of conifers (mainly Abies and Tsuga). The pollen of Chenopodiaceae and Artemisia is in progress. The dinoflagellates are represented mainly in the lower levels. In the Upper Pontian (Bosphorian) the microflora is similar to that one from Middle Pontian but appear some changes: the percentage of conifers (in comparison with deciduous trees), the pollen of Chenopodiaceae Artemisia and the number of reworked palynomorphs, increase.

Concerning the Pontian from Central Paratethys, further we appeal to results of palynological analyses published into the "Chronostratigraphie und Neostratotypen - Ponzien" volume.

The paper of Pantic (1989) contains a general review concerning the palynological studies of Pontian from the former Yugoslavia. The author outlined that palynological studies are related to the exploitations of pontian lignits from different areas belonging to Serbia, Croatia, Bosnia etc. Pantic concludes that the peat bogs from Upper Pontian are similar to "the subtropical swamps in the U.S.A.: DismalSwamp in North Carolina, Everglades in Florida, Okefenokee - Swamp on the Georgia Florida border, and the mangrove swamp on the southern coasts of Florida". 
In the same volume, Nagy (1989) presented the results of palynological analyses from some boreholes from Hungary. In the synthesis paper, Nagy (1992), for the Pontian, establish the PN11 palynological zone, characterized by numerouses spore forms belonging to Stereisporites. Persicariopollis franconicus. P. welzowense, Valerianaceoipollenites neszmelyensis, Intratriporopollenites cordataeformis and a great variety of conifers appear, too.

Planderova - Papsikova (1989) characterized by palynological point of view, the Pontian from western part of Slovakia. The authors concluded that, in the studied Pontian, it comes out that the Miocene termophile elements are in regress, on the other hand, arctotertiary elements proliferate. The forest swamps (Taxodiaceae, Alnus, Salix, ferigi etc.) lay at the basis of form to generating by coals peat bogs. The mountain forests were dominated by Abies, Picea, Tsuga etc. "The climate in the time of sedimentation of the Pontian horizons was probably mild and relatively humid" (I.c.p. 911).

\section{Acknowledgements:}

Thanks to Dr. Sorin Filipescu for the review of the English translation.

\section{REFERENCES}

Ghenea, C., Ghenea, A., (1962), Câteva observațiuni geologice asupra prezenței Ponțianului dintre Tr. Severin şi Baloți, D.S. Inst. Geol., XLVI (1958-1959), p. 199-205, Bucureşti.

Givulescu, R., (1976), Juglans bergonensis in Pontianul din Romania. D.S. Inst. Geol., LXII (1974-1975), 3, p. 183 - 185, Bucureşti.

Marinescu, FI., (1978), Stratigrafia Neogenului Superior din sectorul vestic al Bazinului Dacic. Editura Academiei, 155 p., Bucureşti.

Maxim, I., Al., Petrescu, I., (1968), Plante din Pliocenul de la Derna. Studia Univ. Babeş-Bolyai, s. Geol.-Geogr., 1, p. 7 - 15, Cluj-Napoca.

Nagy, E., (1989), Palynologische Schätzung des ungarischen "Oberpannons" (=Ponzien). Chronostratigraphie und Neostratotypen, Ponzien, p. 890 - 921, Verlag der Jugoslawischen Akademie der Wissenschaften und Künste, Zagreb - Belgrad.

Nagy, E., (1992), A comprehensive study of Neogene sporomorphs in Hungary. Geologica Hungarica, s. palaeontologica, 53, Budapesta.

Pantic, N., (1989), Palynomorphs (spores, pollen, dinoflagellates) from Pontian sediments in Yugoslavia. Chronostratigraphie und Neostratotypen, Ponzien, p. 870 - 889, Verlag der Jugoslawischen Akademie der Wissenschaften und Künste, Zagreb - Belgrad.

Pătruțoiu, I., (2000), Geologia Pliocenului cu lignți dintre Dunăre si Motru.Teza de doctorat, 188 p., Univ. "Babeş-Bolyai", Catedra de Geologie-Paleontologie, Cluj-Napoca.

Petrescu, I., Nicorici, E., Boticaş, C., (1982), Contributions à la connaissance de la palynologie du Pontien à charbons de Sărmăşag, bassin de Şimleu (NO de la Roumanie). Paleobotany - Palynology Symposium, p. 74 - 77, Cluj-Napoca.

Petrescu, I., Nicorici, E., (1979), Biostratigrafia depozitelor pliocene din forajele de la Roşiori Oradea şi Voievozi. Nymphaea, VII, p. 77 - 100, Oradea. 
Petrescu, I., Nicorici, E., Wanek, Fr., Blidaru, I., (1979), Date biostratigrafice cu privire la Neogenul din forajul hidrogeologic de la Oradea - Est (F 11). Nymphaea, VII, p. 111 129, Oradea.

Petrescu, I., Kolovas, A., (1982), Cercetări palinologice asupra Ponțianului de la Darova - Lugoj. Contribuții botanice, p. 117 - 130, Cluj-Napoca.

Petrescu, I., Nicorici, E., Codrea, V., (1982), Palinostratigrafia formațiunilor ponțiene cu ligniți, din Bazinul Lugoj. Studia Univ. Babeş-Bolyai, s. Geol.-Geogr., XXVII, 1, p. 20 - 33, Cluj-Napoca.

Petrescu, I., Mălan, L., (1991), Contribuții la cunoaşterea microflorei din Neogenul superior de la est de Turnu Severin. Contribuții botanice, p. 135+143, Cluj-Napoca.

Planderova, E., Papsikova, M., (1989), Microfloristic characterisation of the pontian from Slowakia. Chronostratigraphie und Neostratotypen, Ponzien, p. 906 - 921, Verlag der Jugoslawischen Akademie der Wissenschaften und Künste, Zagreb - Belgrad.

Roman, St., Papaianopol, I., (1982), Données microfloristique et macrofaunistiques sur les depots postméotiens de la zone des plis diapires externes de Muntenie. Paleobotany Palynology Symposium, p. 82 - 87, Cluj-Napoca.

\section{PLATES}

\section{Plate 1 (1000x)}

Fig. 1. Ephedripites (D.) tertiarius W. Kr. 1970

Fig. 2. Laevigatisporites haardti (Pot. et Ven. 1934) Th. et Pf. 1953

Fig. 3. Stereisporites (St.) megastereis W. Kr. 1963

Fig. 4. Cedripites crassiundulicristatus (Stelmak 1960) W. Kr. 1971

Fig. 5. Corsinipollenites oculusnoctis (Thg. 1940) Nakoman 1960

Fig. 6. Zonalapollenites igniculus (Pot. 1931) Th. et Pf. 1953

Fig. 7. Nyssapollenites kruschi (Pot. 1931) Nagy 1969

Fig. 8. Scabiosaepollenites minimospinuosus Nagy 1969

Fig. 9. Chenopodipollis multiplex (Weyl. et Pf. 1957) W. Kr. 1966

Fig. 10. Ericipites callidus (Pot. 1931) W. Kr. 1970

\section{Plate 2 (1000x)}

Fig. 1. Leiotriletes wolffi W. Kr. 1962 brevis W. Kr. 1962

Fig. 2. Zonalapollenites maximus (Raatz 1937) W. Kr. 1971

Fig. 3. Malvacearumpollenites bakonyensis Nagy 1962

Fig. 4. Lonicerapollis gallwitzi W. Kr. 1962

Fig. 5. Piceapollis planoides W. Kr. 1971 (800x)

\section{Plate 3 (1000x)}

Fig. 1. Abiespollenites cedroides (Thomson 1953) W. Kr. 1971 (800x)

Fig. 2. Abiespollenites dubius (Chlonova 1960) W. Kr. 1971 (800x)

Fig. 3. Tubulifloriidites grandis Nagy 1969

Fig. 4. Alnipollenites verus (Pot. 1931) Pot. 1934

Fig. 5. Valerianaceoipollenites neszmelyensis Nagy 1992

Fig. 6. Persicarioipollis franconicus W. Kr. 1962 


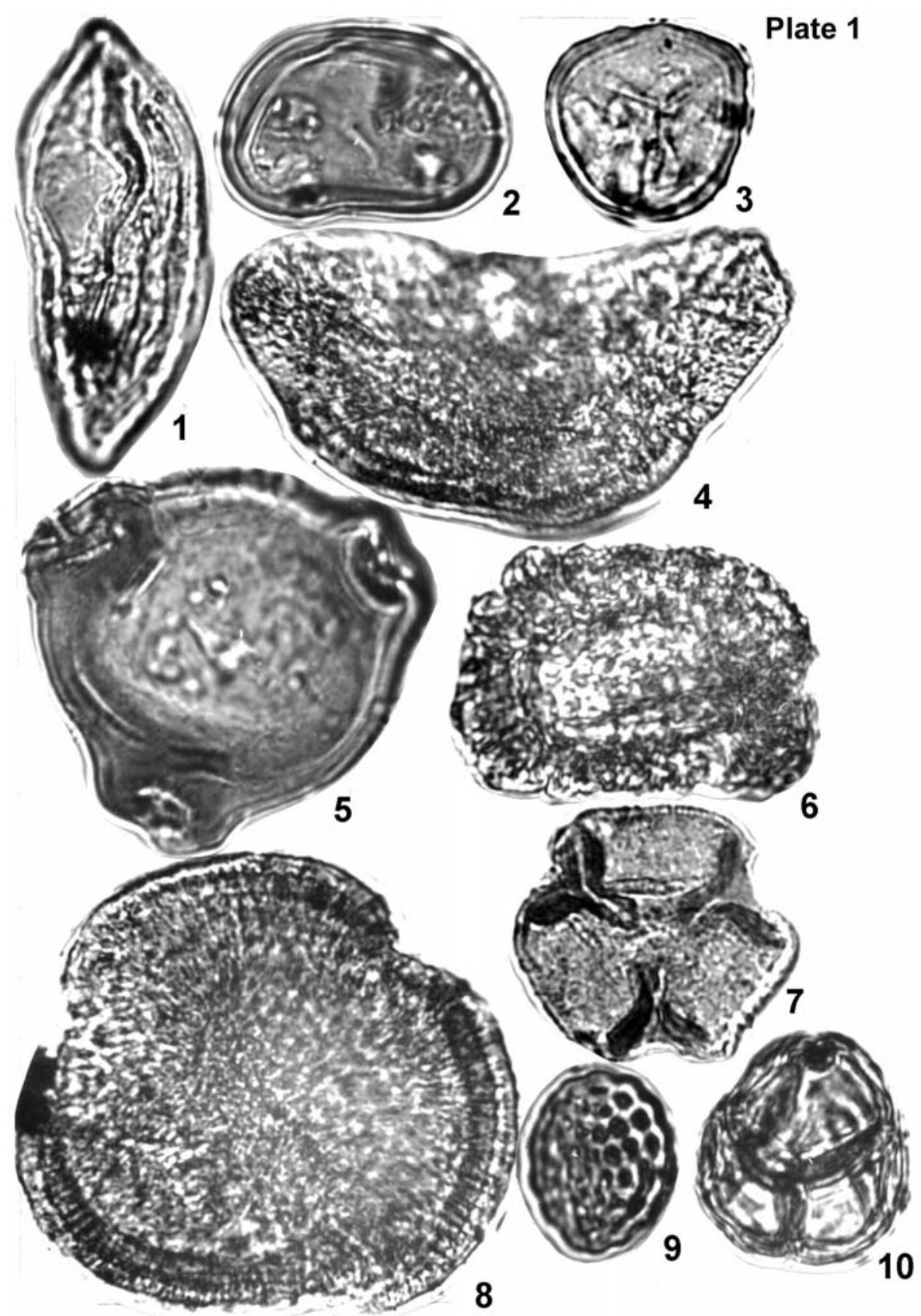




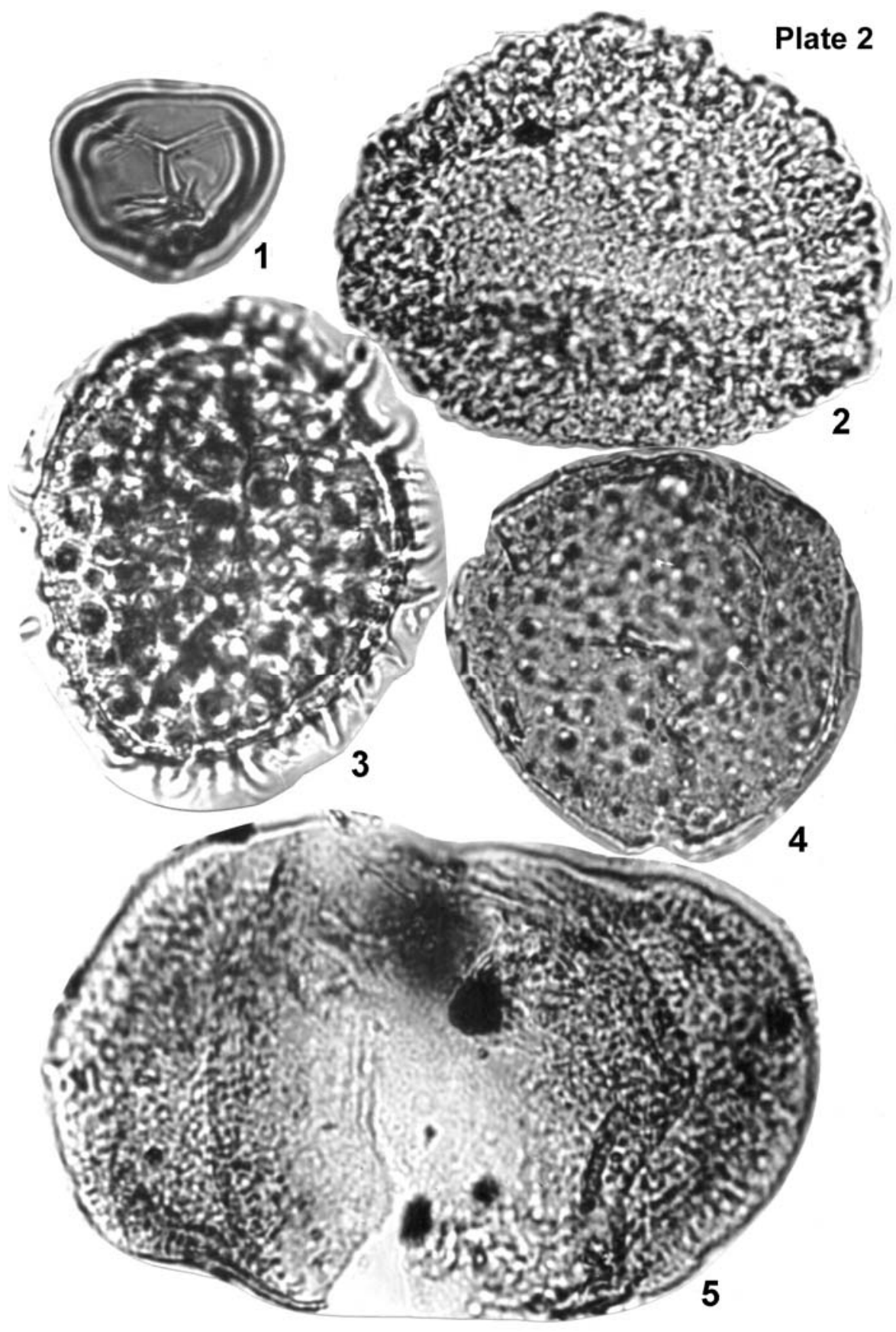




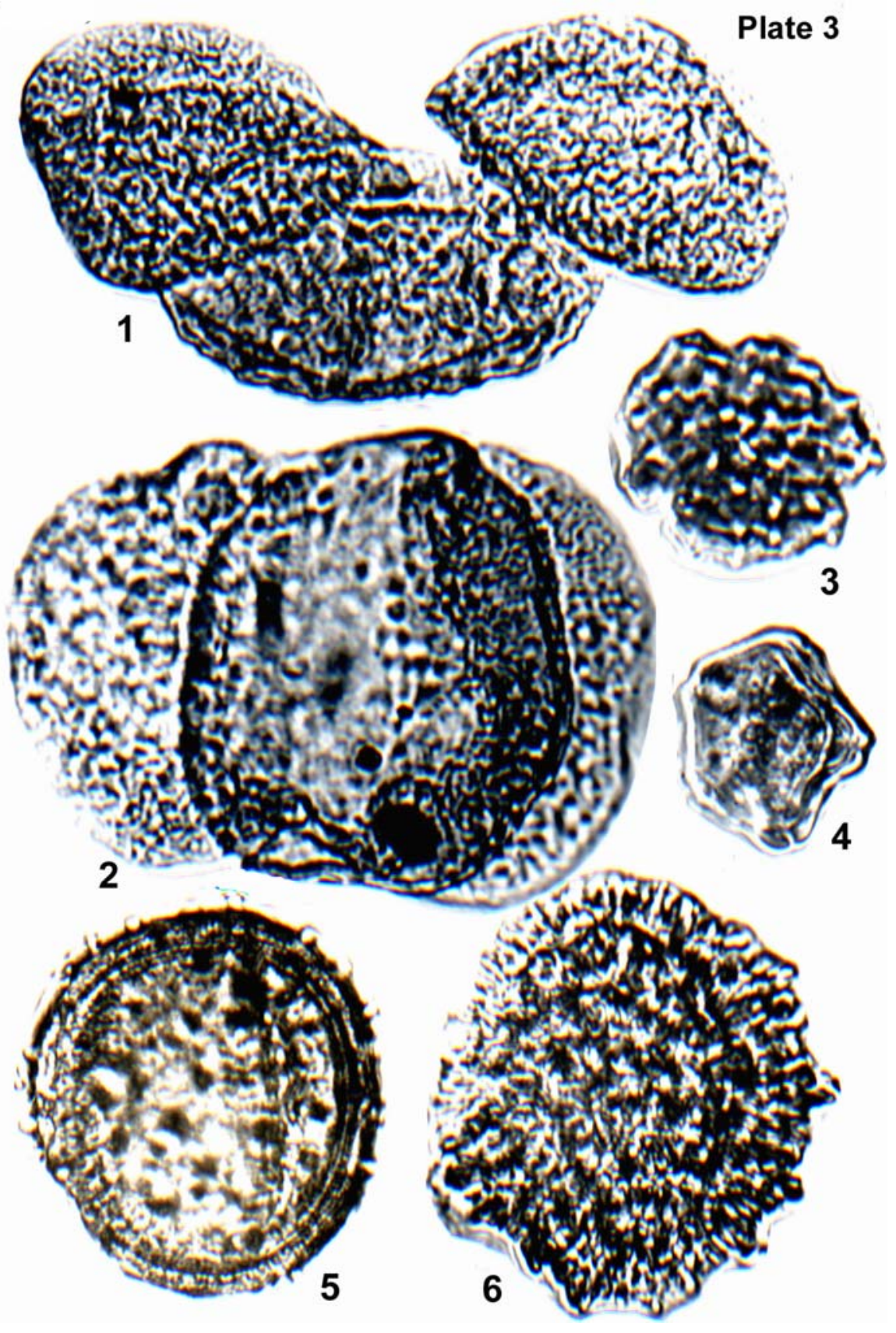

